\title{
The case against a perpetual NPT
}

The conference of the members of the Nuclear Non-Proliferation Treaty must strive to continue the treaty, but not to make it perpetual; the world will need regular reminders of the hazards of proliferation for decades to come.

THE conference of the members of the Nuclear Non-Proliferation Treaty (NPT) due to open in April at Geneva will be a formative experience for all concerned. There are two crucial questions to be decided. Will the treaty continue in being? And will its members agree that it should continue in being indefinitely? The hope must be that the former question will be answered in the affirmative. The second is trickier. Even those who regard the NPT as a linchpin of international security should not be too downcast if the members settle for another fixed term.

As treaties go, the NPT is every bit as important as its well-wishers say. In 25 years, it has been a powerful restraint on the spread of nuclear weapons. Those who doubt that have only to consider what the world would now be like if there had been no presumption of law-breaking to level at countries such as Iraq and North Korea (both members of the treaty) in the past few years. Similarly, without the NPT, the chaotic breakup of the Soviet Union since 1990 might well have made to seem legitimate the sale of chunks of one of the world's largest stockpiles of fissile material. Of course, the NPT has not been ideal. Both Iraq and North Korea chose to break the rules, but were found out. More seriously, several important putative nuclear powers (Israel, India and Pakistan, for example) remain outside the treaty. Yet the NPT has helped to make the world a safer place.

Can that continue? Next month's conference will raise a piquant dilemma for the non-nuclear members of the treaty. From the outset, many of them have complained that the treaty is asymmetrical between nuclear powers and themselves; non-nuclear powers must put up with inspection of their nuclear installations, but nuclear powers are formally exempt. And a quid pro quo for that asymmetry, the undertaking in the NPT that the nuclear powers would provide technical assistance in the exploitation of civil nuclear technology to those in need of it, now seems hollow.

Yet in normal times, the traditional nuclear powers would have been able to boast that they have amply fulfilled their other promise in the NPT to pursue measures of strategic arms control "in good faith". Central Europe is no longer bristling with nuclear weapons, thanks to the agreement on strategic weapons of intermediate range. There are also agreements signed, but not yet ratified, on the balanced reduction of weapons of longer range, while both the United States and Russia (inheritor of the Soviet Union's obligations) appear to have given up ambitions to build defences against strategic weapons. Is that not enough, the nuclear powers would ordinarily be asking?

They know, without waiting for the answer, that present circumstances are too confused for even this splendid record to suffice in present circumstances. One snag is the ambiguity of China's position on proliferation and on strategic issues in general; there has been nothing like the dialogue with the West that paved the way for the eventual rapprochement with the former Soviet Union. Similarly, the continuation of Israel's cryptonuclear status, as that of India, goads other states towards proliferation. That is why the nuclear powers now seem ready to go a big step further, offering a comprehensive test-ban treaty (CBT) as further earnest of their good faith. Will that pull round the nonnuclear doubters? Especially now that the United States has abandoned a condition allowing the resumption of testing after a ten-year break, there is a good chance.

Even so, the non-nuclear powers will not willingly sign up for a perpetual continuation of the NPT - nor should they. Fifty years after the nuclear explosion at Alamagordo in the Nevada Desert, one thing is certain: the knowledge of nuclear weapons, of their destructiveness and of their military influence as deterrents will not simply melt away. As the decades ahead roll by, it is inevitable that bigger or smaller powers will hanker after these trappings of power. Who can say what the effects of such developments would be on now-pacifically minded governments? At least while the present nuclear powers intend keeping part of their stockpiles (and intend keeping them in working order), even a CBT will not persuade non-nuclear powers to sign a perpetual treaty.

Indeed, a perpetual treaty, by making it seem that the problem of proliferation had been solved, would weaken the fight against proliferation. The quinquennial review conferences of the NPT, often irritating for the nuclear powers, have nevertheless kept the need to battle against proliferation on the public agenda. It is not as if a CBT would be the last step towards nuclear sanity. Why not, next, an agreement (safeguarded by inspection) to halt the production of fissile material for other than peaceful purposes? And who is to set up and manage the stockpiles of fissile material that will require international safeguarding when civil nuclear power comes into its own again? Only regular formal discussions between like-minded governments will keep those questions alive. That is why the best outcome of this year's conference will be a renewal of the NPT for 25 years, with regular meetings every five years. 